\title{
HISTORICAL AND PEDAGOGICAL ANALYSIS OF THE SPECIFICITY OF PROFESSIONAL EDUCATION DEVELOPMENT IN NATIONAL EDUCATIONAL SPACE
}

\section{Pahuta M. V.}

\section{INTRODUCTION}

The problem of reformation and development of the vocational education system in Ukraine is one of the most topical and complex in the national pedagogical science, the solution of which requires a thorough historical and pedagogical analysis of all aspects of its formation and development. This will allow us to see an objective picture of its functioning and is extremely important for the modernization of the whole system of vocational education in Ukraine, since the current state of the national system of vocational education, its content and character is largely due to the historical experience of its development.

P. Luzan and O. Vasyuk state that "getting acquainted with the ways of development of the theory and practice of education and training in different historical periods, in the conditions of different socio-economic formations, promotes the development of the correct attitude to the pedagogical heritage, allows to use the experience of the past in modern conditions critically, gives an opportunity to trace the genesis of many pedagogical problems and phenomena." 1

Therefore, the analysis of the historical processes of the formation of the system of vocational education in Ukraine is an extremely important and urgent task. Since the uncertainty of many historical and pedagogical aspects of the formation of the vocational education system in Ukraine and their impact on the modern processes of its transformation do not allow to trace the genesis of many pedagogical problems and phenomena fully and use the existing historical experience to solve them in modern conditions.

At all stages of development, humanity was trying to solve the important task of passing working and professional experience from

1 Лузан П. Г., Васюк О. В. Історія педагогіки та освіти в Україні : навчальний посібник [2-ге вид., доп. і перероб.]. К. : ДАКККіМ, 2010. 296 с. Ст. 6. 
generation to generation. This, of course, actualized the development of vocational pedagogy and vocational education. However, historically, social work is divided into mental and physical work, and this led to differentiation in the history of pedagogy of primary vocational and higher education. The history of vocational secondary education stands apart, as this branch of vocational education stood out much later than the others ${ }^{2}$. In view of this, the history of these components of vocational education is considered separately in scientific and educational editions. However, in our opinion, the history of vocational education should be considered integrated as a coherent system that includes all its subsystems - from vocational guidance to postgraduate education. Only a systematic approach is capable to provide a comprehensive study of the development of vocational education in all its diverse components.

\section{The development of vocational education on Ukrainian lands in the XI-XVth centuries}

The complexity of the study of the historical and pedagogical basis of national vocational education is also connected with the difficult way of its development and the variety of interpretations of basic concepts in this field of pedagogical science. Historical studies indicate that the foundations of professional education in modern Ukraine were laid in the XIth century at the time of Kyivan Rus, when Yaroslav the Wise at Sofia of Kyiv established a school of translators and copyists ${ }^{3}$, the so-called "navchannia knyzhnogo" ("book training"), which later became widespread throughout the country. It should be noted that these schools provided higher education than the conventional literacy schools of that time. They focused on the study of three major subjects at the time: grammar, rhetoric and dialectics. After completion one's studies at this school, the student had to make his own project - to compile his own book - an "izbornyk" (an izbornyk - a handwritten compilation in Kyivan Rus, which consisted of selected texts and excerpts from earlier books and translations based on the study and understanding of existing texts), interlace and illustrate it. After this peculiar examination for the right of

2 Профессиональная педагогіка : учебник для студентов, обучающихся по педагогическим специальностям и направлениям / под. ред. С. Я.Батышева, А. М. Новикова. М. : Издательство ЭГВЕС, 2009. 456 с. Ст. 27.

${ }^{3}$ Артемова Л. В. Історія педагогіки України. К. : Либідь, 2006. 419 с. Ст. 41-42. 
professional activity, the graduate was given one of the qualification levels: the lower one - for keeping trade, business and household records, and the higher one - for writing church and theological books, chronicles and other important works of that time ${ }^{4}$.

P. Luzan and O. Vasyuk mention an even earlier dating of the emergence of the school of "navchannia knyzhnogo" in their works. In particular, they state that "The first testimony of the schools of "navchannia knyzhnogo" in Rus' is dated 988. It was opened by Prince Volodymyr in Kyiv at the tithe church. The students who came to school already had primary education, that is, they were able to write and read. It was a higher education institution, which taught "seven free arts" at that time was given a serious education. ... 300 children were enrolled in the school ${ }^{5}$. Such a number of highly educated people, prepared during the reign of Prince Volodymyr, further enabled his son Prince Yaroslav the Wise to make an important step in the development of education and culture of Kyivan Rus'.

In fact, from now on we can speak about a certain system of vocational training on the territory of modern Ukraine. During his reign $(1019$ - 1054), Yaroslav the Wise opened schools of "navchannia knyzhnogo" not only in the capital of the principality - Kyiv, but also in other big cities. Thus, until the 13th century, such schools (in essence, the first professional educational institutions) operated in such cities of Kyivan Rus' as: Novgorod, Pereyaslav, Suzdal, Volodymyr, Chernihiv, Polotsk, Murom, Turov, Rostov, etc., in total in eighty-seven ancient Rus' cities. Typically, such vocational schools were under full state tutelage and were established in princely courts ${ }^{6}$.

From the middle of the XII century the process of decline of the Kyiv state began. The direct heir of the political and cultural tradition of Kyivan Rus was the Galicia-Volyn principality, which continued to use the educational policy of Yaroslav the Wise.

However, as early as the second half of the fourteenth century, most ethnic Ukrainian lands were divided between the Grand Duchy of Lithuania and the Kingdom of Poland. Accordingly, vocational

4 История педагогики и образования. От зарождения воспитания в первобытном обществе до конца XX в. : Учебное пособие для педагогических учебных заведений / Под ред. академика РАО А. И. Пискунова [2-е изд., испр. и дополн.]. М. : ТЦ «Сфера», 2001. 512 с. Ст. 82-83.

5 Лузан П. Г., Васюк О. В. Історія педагогіки та освіти в Україні : навчальний посібник [2-ге вид., доп. і перероб.]. К. : ДАКККіМ, 2010. 296 с. Ст. 22.

${ }^{6}$ Артемова Л. В. Історія педагогіки України. К. : Либідь, 2006. 419 с. Ст. 50-52 
education on these lands evolved differently, depending on the educational policies of those states that included Ukrainian lands. During this period, Ukrainians felt better under the rule of the Lithuanian principality, which largely adopted the language, traditions, culture and way of life of Ukrainians and did not interfere with their development. Thus, the so-called Church Slavonic language became the main language of government, justice and education. Little is known about the state of education at that time, including vocational education. The most educated at that time was the clergy, which maintained schools and other educational institutions. In the monasteries, including Kyiv-Pechersk, Mykhailivskyi and others, as well as in some places, there were fixed schools in the churches, where capable students studied reading, writing, theology, literature and Greek. Education on the territory of the Lithuanian principality, including the former lands of Kyivan Rus', was similar to Western Europe $7: 8$

The situation was somewhat worse on the lands that were under the control of the Kingdom of Poland. With respect to the Ukrainian people, Poland pursued an aggressive assimilation and militia policy. Ukrainians were evicted from major cities, Ukrainian was displaced from state, church and educational life and replaced with Latin and Polish. Later the situation became only more complicated. Thus, in 1569, as a result of the Lublin Union, much of the Ukrainian lands, which had previously been under the rule of the Lithuanian principality, came under the control of Poland. Poland's aggressive policies aimed at the oppression and assimilation of Ukrainians, in particular the ruling class, led Ukrainian aristocrats to renounce their language and culture.

This process provoked the loss of a class that contributed to the development of national culture and education, and a sense of ethnic identity. However, the 16th century is characterized by the fact that the Ukrainian clergy and Orthodox fraternities began to pay greater importance to education, and schools at churches and monasteries became widespread. Thus, under the pressure of progressive forces, Polish King Stefan Batoryi granted the permission to Vilenskyi Brotherhood to open its own schools. And since 1858, these privileges extended to all fraternities of the Lithuanian principality and Galicia,

\footnotetext{
${ }^{7}$ Артемова Л. В. Історія педагогіки України. К. : Либідь, 2006. 419 с. Ст. 79-81.

8 Лузан П. Г., Васюк О. В. Історія педагогіки та освіти в Україні : навчальний посібник [2-ге вид., доп. і перероб.]. К. : ДАКККіМ, 2010. 296 с. Ст. 31.
} 
thereby facilitating the opening of pro-Ukrainian church, monastery and fraternal schools.

At these schools, children studied alphabet, prayers, read the psalter, or "the Apostle". The students were taught writing and cursive, which was used in the act of writing and record keeping, as well as the number (counting). There were secular, protestant, and jesuit schools in the cities. They usually studied Latin, Greek and Polish, the basics of Christian ethics or theology, mathematics, dialectics, rhetoric, history, geography, cosmography, natural science, much less philosophy and Church Slavonic ${ }^{9}$.

At that time, Ukrainian education managed to reach a sufficiently high level, practically solid literacy of the population was achieved, and the level of education and professionalism of the Ukrainians of that time, even aroused admiration in foreigners ${ }^{10}$.

Typically, the training of manual workers in the fourteenth - first half of the sixteenth centuries was carried out in large cities, whose work activity was organized on a guild principle. For example, in Lviv construction work was carried out by workshops (workshop masters) of carpenters and painters. Therefore, the main form of vocational education at that time was vocational training in the workshops, which was carried out by the method of individual apprenticeship and it lasted usually 3-4 years. Thus, the statute of the Lviv masonry, approved in 1572, stipulated the duration of training for bricklayers of at least three years and stone masonry - four years. After this term, a student had to take a final exam. The students who successfully passed the exam were given the status of assistant companion (apprentice) and were required to work as apprentice (assistant master) for four years ${ }^{11}$. The practice of workshops operating on the lands controlled by Poland stipulated: a student who wanted to become a master craftsman, after completing his training and leaving four years in the status of assistant master (apprentice), was obliged to go on a two-year journey to work in others cities or abroad.

\footnotetext{
${ }^{9}$ Артемова Л. В. Історія педагогіки України. К. : Либідь, 2006. 419 с. Ст. 82-86.

10 Лузан П. Г., Васюк О. В. Історія педагогіки та освіти в Україні : навчальний посібник [2-ге вид., доп. і перероб.]. К. : ДАКККіМ, 2010. 296 с. Ст. 47.

${ }^{11}$ Історія Львова у документах і матеріалах / М. В. Брик, У. Я. Єдлінська. К.: Наукова думка, 1986. 426 с. Ст. 36.
} 


\section{The development of vocational education on Ukrainian lands in the XVI - XVIII th centuries}

The subsequent development of vocational education in Ukraine in the 16th-18th centuries was associated with individual craft and professional apprenticeship, as well as the activities of fraternal schools and the first higher education institutions. The first fraternal school on the territory of modern Ukraine was founded by Uspenskyi (Stavropigyiskyi) fraternity in Lviv (1586), and the graduate of this fraternal school was Petro Mohyla, the founder of Kyiv Mohyla College $^{12}$. According to its model, many brotherly schools appeared in different cities of Ukraine: Halych, Gorodok, Rohatyn, Stryi, Drohobych, Mykolaiv, Komarno, Yaroslav, Holm, Krasnostav, Zamost (1606), Bilske, Brest, Volodav, Pinsk, Kyiv (1615), Stryatyn, Vinnytsia, Nemyriv, Kamianets-Podilskyi, Medzhybozh, Lutsk (1620), Volodymyr-Volynskyi, Dubno, Kremenets, etc.

In 1576 a Slavonic-Greek-Latin school was founded by Prince Vasyl-Konstantyn Ostrozkyi, which was later given the status and the name of Ostrog Slavic-Greek-Latin Academy. Although the name "academy" instead of "university" was affixed to it - as it was accepted in the countries of Western Europe, the educational process in it was organized on the model of the best Western European universities of that time.

Although fraternal schools provided better education, they were secondary educational establishments ${ }^{13}$. Therefore, the further stage of their development was the transformation of some fraternal schools into higher education institutions. Thus, in 1632, via the unification of Kiev Brotherhood and Kiev Lavra Schools, the Kyiv-Mohyla College was established, which in 1658 (under the Hadiach Agreement) was granted the right of higher education and the title of "academy", which was officially recognized and confirmed by the tsarist diploma in 1701 and was named Kyiv Academy. With the assistance of Kyiv-Mohyla Academy, colleges were opened and operated in Chernihiv (1700), Kharkiv (1726), and Pereyaslav (1730).

12 История педагогики и образования. От зарождения воспитания в первобытном обществе до конца XX в. : Учебное пособие для педагогических учебных заведений / Под ред. академика РАО А. И. Пискунова [2-е изд., испр. и дополн.]. М. : ТЦ «Сфера», 2001. 512 с. Ст. 87.

13 Лузан П. Г., Васюк О. В. Історія педагогіки та освіти в Україні : навчальний посібник [2-ге вид., доп. і перероб.]. К. : ДАКККіМ, 2010. 296 с. Ст. 51. 
An important stage in the formation and development of national education on the territory of modern Ukraine in the Renaissance was played by the Cossack Zaporizh Republic, which united the lands of modern Dnipropetrovsk, Zaporizhzhia, Kherson, Mykolaiv and partly Donetsk regions. The first school on Cossack lands was opened in 1576 near Novomoskovsk, since 1602 this school was named monastic because it operated at Pustynno-Mykolaiv Military Monastery. It prepared readers and singers for all churches and parishes of Zaporizhzhia region and other Ukrainian lands ${ }^{14}$.

In Sich and in all administrative centers, where Cossack regiments were located (Uman, Bratslav, Chernihiv, Sumy, Izium, Fastiv, etc.), sich or regimental schools were established, in which the spirit of the Cossacks, democratic principles and ideas of folk pedagogy prevailed ${ }^{15}$.

At the main sich school of that time, which was at the level of the best fraternal schools, they studied Church Slavonic, Russian and Latin, pyotics, rhetoric, arithmetic and geometry, geography, astronomy, poetics and even, to write poetry in Latin. Special role was given to the military-physical education of young men. Among the disciplines in sich and regimental schools of that time, considerable attention was paid to the study of arithmetic and geometry, geography, astronomy, military affairs, a system of selection and training of young people for Cossack service $^{16}$.

At the same time, a lot of attention was paid by the Cossacks to the aesthetic education of young people. The Cossacks highly appreciated the ability to play musical instruments, sing and dance. A number of Cossack art schools were opened, special schools of military regimental music operated. In 1737, a music school was opened in the town of Hlukhiv, in which the bandurists, violinists and harpsichords were trained. Also, music departments operated at almost all sich, regiment and general schools of the Zaporizh Army. After the graduation from sich and regimental schools, the best students usually entered KyivMohyla Academy, and a large part of the graduates worked as clergymen and teachers in Cossack Jurassic schools. In 1754, Yakov Gnatyukovych organized the first specialized school in Sich to train

\footnotetext{
${ }_{15}^{14}$ Артемова Л. В. Історія педагогіки України. К. : Либідь, 2006. 419 с. Ст. 131-132.

15 Артемова Л. В. Історія педагогіки України. К. : Либідь, 2006. 419 с. Ст. 134.

16 Лузан П. Г., Васюк О. В. Історія педагогіки та освіти в Україні : навчальний посібник [2-ге вид., доп. і перероб.]. К. : ДАКККіМ, 2010. 296 с. Ст. 61.
} 
regimental officers, military chancellors and various administrative persons ${ }^{17}$.

By then, the Ukrainian national system of education and training achieved considerable success. Almost the entire territory of modern Ukraine was covered by a dense network of deacon, church, monastery, Cossack, fraternal, artisan schools and colleges, schools of folk arts and crafts, and higher educational institutions. At that time, Ukrainian education practically rose to the European level, and international cultural, scientific and educational ties with many European countries were established, and the Ukrainian ecclesiastical, public, scientific, pedagogical and Cossack military elites were crystallized ${ }^{18}$.

In 1667, under the terms of Andrusiv Truce, the Moscow state and Poland divided Ukraine into two parts, the Right Bank, which went to Poland and the Left Bank, which went to Russia. The new owners did not care about building Ukrainian statehood and education. Educational conditions in Ukraine, including the Left Bank especially after the destruction of the Hetmanate in 1764 and the destruction of the Zaporizhzhia Sich in 1775, especially worsened, that was accompanied by massive eviction of Ukrainians from northern regions and replacement them by Russians and German colonists ${ }^{19}$.

In general, the end of the XVII - beginning of the XVII centuries is characterized by the gradual decline of individual artisan and workshop apprenticeship and the beginning and development, on the territory of modern Ukraine, secular education, which was conditioned by the character of the development of the national philosophical and pedagogical thought of that time. Kyiv-Mohyla Academies, Lviv University, colleges, fraternal, sich and regimental schools.

\section{The development of vocational education}

\section{on Ukrainian lands in the XVII - XIX th centuries}

With the loss in the XVII century political and state independence, the destruction of the Cossacks at that time the Ukrainian education system was hit blow by the blow. Polish, Russian, Austro-Hungarian reactionaries sought to destroy the Ukrainian education system. The Ukrainian language was forbidden, Ukrainian schools, colleges were

\footnotetext{
${ }^{17}$ Артемова Л. В. Історія педагогіки України. К. : Либідь, 2006. 419 с. Ст. 134-137.

18 Лузан П. Г., Васюк О. В. Історія педагогіки та освіти в Україні : навчальний посібник [2-ге вид., доп. і перероб.]. К. : ДАКККіМ, 2010. 296 с. Ст. 42-65.

${ }^{19}$ Артемова Л. В. Історія педагогіки України. К. : Либідь, 2006. 419 с. Ст. 147-148.
} 
closed, higher education was declining. The invaders imposed foreign language, culture, traditions and customs on Ukrainian youth. National identity, distinctive statehood and culture were destroyed. Thousands of educated, cultural and scientific figures were forced to leave Ukraine ${ }^{20}$.

It was natural that in such conditions the process of formation and development of vocational education in the territory of modern Ukraine slowed down considerably. Ukraine in the XVII - XIX centuries turned into a province increasingly with time-lagged education. After all, the foreign government paid little attention to the establishment and development of a holistic system of education in Ukraine, including crafts and agriculture. In a slightly better situation, there was a college education that was popular with wealthy young people. However, it was not so good, as teaching was usually done in a foreign language, not in the Ukrainian language, and ethnic Ukrainians' access to higher university education in Ukraine was significantly complicated and artificially restricted.

In particular, L. Artemova notes that "The reactionary activities of the tsarist government impeded the creation of the Ukrainian national school, hindered the spread of literacy among the common people who spoke Ukrainian. In the 60-90s of the XIX th century there were almost no schools with Ukrainian language in Ukraine. Education ministers S. Uvarov and D. Tolstoy sought the complete russification of all nonRussian peoples within the empire. St. Volodymyr's University was opened in Kyiv. "The university is my creation," said S. Uvarov. "But I will be the first to eliminate it if it does not fulfill its purpose ... to spread Russian education and Russian nationality in the western lands of Western Russia." 21

Practically no better things were in Western Ukrainian lands under the rule of Austria-Hungary. Thus, only in 1848 Ukrainians got political and civil rights almost equal to Polish for a very short period of time. At this time, the Main Russian Council was established in Lviv, which was recognized as the official representative of the Ukrainian population of Galicia in Vienna. One of the priority areas of the Russian Council's work was the development of the Ukrainian language, culture and education. With its active assistance, a number of laws were adopted that somewhat changed the educational policy in Galicia, Bukovyna and Transcarpathia and allowed educational institutions in these territories to

${ }^{20}$ Артемова Л. В. Історія педагогіки України. К. : Либідь, 2006. 419 с. Ст. 148.

${ }^{21}$ Там само. Ст. 154. 
teach in the Ukrainian language. At the same time, in 1848, the Department of Ukrainian was opened at Lviv University, and the parish and trivial schools were transfered into the Ukrainian language in the areas where the majority of the population was Ukrainian, and in many high schools the Ukrainian language was taught as a compulsory subject.

However, this period did not last long. Already in 1851, the Main Rus' Rada was dissolved, and under the pressure of the pro-Polish forces, Ukrainians began to lose their positions in the political and public life of the state and in education. New Polish educational establishments were beginning to open on Ukrainian lands, Ukrainian language schools and gymnasiums were closed. In 1856, the compulsory study of the Ukrainian language in high schools was abolished, the entry of Ukrainians into the University of Lviv was significantly restricted and complicated.

The Austrian educational reforms of the 1860s and 1870s were unfavorable to the Ukrainians and entirely to the Ukrainian lands. Thus, since 1867, in accordance with the law governing the language of teaching in secondary and public schools, Polish has become compulsory in all educational institutions. The whole administrative structure of the region, practically all educational institutions, including the University of Lviv, were polonized, and all management positions were given to the Poles. In general, we can state that at the end of the nineteenth century the Ukrainian lands in educational development were among the most backward in Austro-Hungarian Empire.

However, in the nineteenth century, due to the struggles of the progressive community and in accordance with socio-economic needs, there was a slight development of vocational and higher education on the territory of modern Ukraine. The centers of contemporary educational and scientific thought, training of scientists, teachers, doctors, lawyers were Lviv, Kyiv, Kharkiv (1805), Novorossiysk (Odessa) universities, Hlukhiv Teacher's Institute (1874), Nizhyn Historical and Philological Institute ( 1875), Korostyshiv Teacher Training Seminary (1869), Kherson Teacher Training Seminary (1871), Ackerman Seminary (1872), Lviv Teacher Training Seminary, Chernivtsi Teacher Training Seminary, Mukachevo Teacher Training Seminary, Uzhgorod Seminary, Reyaslav Teacher Training Seminary (1878), Sambir Teacher Training Seminary (1900), Richelieu (1817) and Kremenets (1819) Lyceums, Nizhyn Gymnasium of Higher Sciences of Prince Bezborodko (1820), which was gradually transformed into physical and mathematical (1832) 
and law (1840) lyceums and other professional educational institutions. Specialists in industry and agriculture were trained by the Kharkiv Veterinary Institute (1851), Kharkov Technological University (1885), the Kyiv Polytechnic Institute (1898), the Lviv Polytechnic Institute (1844), the Academy of Veterinary Medicine in Lviv (1897), Ekaterynoslav Higher Mining School (1899), etc.

In general, neither the Austro-Hungarian nor the tsarist governments paid attention to the development of the education system on their lands. Thus, I. Likarchuk notes that only since the late 1980s, after the adoption of the "The Basic Provisions on Industrial Schools" in Ukraine, as well as throughout the territory of tsarist Russia, the creation of systems of industrial, agricultural and women's education started and were formed their governing bodies. These educational systems existed before October 1917 coup. None of the governments operating on the territory of Ukraine from 1917 to 1920 , despite repeated attempts, did not manage to create a system of vocational education and organizational structure for managing it due to the short duration of their existence $^{22}$.

\section{The development of vocational education on Ukrainian lands in the XX - XXI th centuries}

The beginning of the twentieth century proved to be particularly dynamic and dramatic both in the life of the Ukrainian people and in education. The collapse of the Austro-Hungarian Empire and the fall of the Western Ukrainian People's Republic led to the occupation of Eastern Galicia and Western Volyn by Poland, Transcarpathia (Subcarpathian Rus) by Czechoslovakia, Northern Bukovina, and much of Bessarabia by Romania. Each of the new political regimes particularly severely and consistently destroyed national education and schools, including vocational ones, in the subordinate Ukrainian lands. The rigid assimilationist policies of the dominant regimes became a significant obstacle to the acquisition of professional knowledge by national minorities, especially by Ukrainians. Almost all the educational establishments operating on these lands were translated into teaching in the language of the dominant regime: Polish, Romanian, Hungarian, Czech, Russian. Such unfavorable conditions created a disproportion

22 Лікарчук І. Управління системами підготовки кваліфікованих робітників в Україні (1888-1988 роки) : монографія. К. : Вища школа, 1998. 256 с. Ст. 40-85. 
between the needs of the Ukrainian population in vocational education and the actual number of vocational schools in which they could obtain this education.

Performing a retrospective analysis of the training of workers in the production of I. Zhuk indicates that the process of formation and development of the system of training of workers in the XIX - early $\mathrm{XX}$ th centuries was largely determined by the development of industry, the main stages of which necessitate the centralization or decentralization of the system of training of workers. Thus, industrial growth in the late nineteenth century was one of the factors behind the formation of a holistic system of vocational education aimed at training highly skilled workers. Therefore, it is possible to speak about the first stage of formation and development of the system of training of workers, within which, at the end of the nineteenth century, the first professional educational establishments operated on the basis of private initiative, and at the beginning of the twentieth century a system of special education was created ${ }^{23}$.

Analyzing the structure of educational systems that operated in Ukraine at the end of the 19th - beginning of the 20th centuries, I. Likarchuk notes that there were 22 types of lower vocational education establishments operating on the territory of Ukraine from 1888 to 1917. Among them, the most widespread were lower technical, agricultural and handicraft schools, lower handicraft and agricultural schools, rural artisanal workshops and forest schools, artisan classes and departments at educational establishments of different types, various technical, handicraft courses ${ }^{24}$.

The next stage of the development of vocational education in the territory of modern Ukraine is largely determined by the formation of the USSR. Thus, the 20-30s of the twentieth century were marked by a sharp shortage of skilled workers, that forced the government of the USSR and Soviet Ukraine in particular to go to the program of mass vocational training of young people, thus stimulating the development of the USSR industry and the beginning of the industrialization of the country.

23 Жук І.Л. Підготовка робітничих кадрів на виробництві: ретроспективний аналіз та оцінка сучасних тенденцій // Демографія та соціальна економіка, 2014, № 2 (22). С. 145-154. Ст. 148.

Лікарчук І. Управління системами підготовки кваліфікованих робітників в Україні (1888-1988 роки) : монографія. К. : Вища школа, 1998. 256 с. Ст. 142. 
I. Zhuk notes that the existing system of training of workers was individual, the training was conducted in the context of professional activity based on the personal experience of the student. However, such a system of education was unacceptable for the rapid training of a large number of skilled workers ${ }^{25}$.

To reduce the gap in economic and industrial development with European countries in the USSR, the Bolsheviks announced a course for rapid industrialization and transformation of the country from agrarian to industrialized. This approach required a large number of relatively skilled workers, and therefore a revision of approaches and public policies in the field of vocational education in general and the training of skilled workers in particular.

To this end, specialized management bodies of the vocational education system, including the training of workers, were established during the years 1920 - 1923. Thus, in 1920, at the first All-Ukrainian meeting in the field of public education, a scheme of public education of the Ukrainian Socialist Soviet Republic was developed. According to it, the system of vocational education was proclaimed an integral part of the entire educational system of Ukraine and divided it into lower (mass) and higher vocational schools, which was enshrined in 1922 in the Code of Laws on Public Education of the Ukrainian SSR. In the same period, factory-based training schools were established, which at that time became the main form of training of skilled workers and the first vocational education unit in the country. The optimal combination of management functions of the People's Commissariat of Education and Ukrholovprofosvita was achieved, and democratic foundations in the management of educational institutions became widespread. The main differences between the Ukrainian vocational education system at that time were, first and foremost, the significant democratization of educational processes, social education and professionalization of young people.

1924-1929 are characterized by the processes of development of the system of vocational education, which resulted in the development and increase of the number of schools of factory training, unification and centralization in the educational field, in connection with which the independence of the organizational structures of management of the

25 Жук І.Л. Підготовка робітничих кадрів на виробництві: ретроспективний аналіз та оцінка сучасних тенденцій // Демографія та соціальна економіка, 2014, № 2 (22). С. 145-154. Ст. 148. 
system of vocational education and training of skilled workers was eliminated ${ }^{26}$.

1929-1932 are characterized by the functioning and development of sectoral organizational structures for managing the systems of training of workers, rapid growth in the number of schools of factory training. For example, the number of students in these schools was more than tripled. Particular attention was paid to the development of a factory-based school system for training specialists in the heavy industry. So, for example, if in 193042351 persons were enrolled in the schools of factory-production training of the People's Commissariat for Industry, then by the beginning of 1932 their number had increased almost in 8 times and amounted to 333251 persons $^{27}$.

The years 1933-1940 are characterized by the continuation of the processes of centralization and unification of the educational sphere, the strict normative regulation of the administrative activity of the heads of educational establishments and the focus on providing narrow-profile training of workers. At the same time, the Ukrainian Soviet Union joined other Ukrainian lands that were under the rule of Poland, Romania, Czechoslovakia (Western Ukraine (1939), Northern Bukovyna and parts of Bessarabia (1940), Transcarpathia (1945)) and the establishment of a single educational policy on the territories of the USSR.

The dual nature of the system of training of workers at that time was that, in addition to training at the Federal Employment Service, which had a special and professional orientation, special production courses were proposed and introduced educational practice, which used the methodology developed by the Central Institute of Labor (CIL). At the production courses created in the structure of industrial enterprises, training of workers was carried out in a short time due to the introduction and use of innovative method of "labor installations" - a system of employment techniques that is brought to automatism and combined labor operations, which are described step by step in instruction cards.

1941-1944 are characterized by German occupation and military operations in Ukraine. With the occupation of Ukrainian lands by German troops, construction of a new pro-German education system

26 Лікарчук І. Управління системами підготовки кваліфікованих робітників в Україні (1888-1988 роки) : монографія. К. : Вища школа, 1998. 256 с.

27 Ханин Г. И. Экономическая история России в новейшее время. - Т. 1 : Экономика СССР в конце 1930-х годов - 1987 г. Новосибирск : Из-во Новосибирск. гос. тех. ун-т, 2008. 516 с. Ст. 97. 
began. Thus, since the autumn of 1941, vocational schools were opened on the Ukrainian lands by the German occupation authorities, which were divided into 4 groups: artisan, industrial, agricultural and trade. The main task of which was to prepare young people for work at enterprises and farms of the Third Reich. Typically, the training periods at these schools were not maintained, and students, at the first request of the occupying authorities, were forced to go to Germany, regardless of the time of study and the level of mastering the curriculum ${ }^{28}$.

In the liberated and uncontrolled territories of the USSR, a system of accelerated restoration of labor reserves was formed, which was called in a short time to eliminate the huge shortage of skilled workers that arose in connection with hostilities. Usually, training was carried out in an extremely short time directly in the workplace by an experienced master mentor.

The years 1945-1958 were characterized by the restoration of the Soviet system of vocational education, the restoration of most educational institutions established in 1929-1940, and the creation of a centralized and tightly regulated system of vocational education, strengthening the interconnections between the general and vocational education systems. At the enterprises numerous schools of labor reserves were created and functioning, which eventually evolved into vocational schools (SVS), and higher educational establishments were restored ${ }^{29}$.

1959-1980 the further improvement of the vocational education system took place, the final transition to a centralized education system was made. The content, curricula and training programs of specialists in higher and secondary vocational schools were unified. Secondary vocational schools (SVS) were being created and developed, in which students could receive not only vocational but also secondary education. Material, technical, educational-methodical and scientific support of professional educational institutions was centrally developed, produced and implemented ${ }^{30}$.

The years 1981-1990 are characterized by significant problems in the economic and political development of the USSR, as well as

28 Жук І.Л. Підготовка робітничих кадрів на виробництві: ретроспективний аналіз та оцінка сучасних тенденцій // Демографія та соціальна економіка, 2014, № 2 (22). С. 145-154. Ст. 149.

${ }^{29}$ Батышев С.Я. Очерки истории профессионально-технического образования в СССР. М. Педагогика, 1981. 351 с. Ст. 143.

${ }^{30}$ Пузанов М., Терещенко Г. Очерки истории профессионально-технического образования в Украинской ССР. К.: Вища школа, 1980. 232 с. Ст. 63-78. 
aggravation of the problems of separation of the educational process of training specialists from the real demands and needs of society.

In 1988, the system of public and vocational education was merged, and tendencies toward a weakening of the centrist foundations and the formation of a state-public system of government were identified ${ }^{31}$.

1991-1994 are characterized by the emergence of Ukraine as a sovereign and independent state. The ways of reforming the vocational education system were searched. There was a formation of a new legal framework for the functioning of the system of vocational education and strengthening of centrist tendencies in management. Various types of educational institutions were created and developed, including private ones.

1995-1999 are characterized by the development and improvement of the new legal framework for the functioning of the system of vocational education, the transition to a multi-level step-by-step system of education.

2000-2013 are characterized by exacerbation of educational problems, search for new educational paradigms for the development of the national system of vocational education, departure from the Soviet system of education and equation for the Western European and American systems, reformation of the education system of Ukraine in accordance with the requirements of the Bolognia process, weakening of the centrist foundations, increasing of autonomy of educational establishments .

2014-2019 are characterized by the significant innovations in the vocational education system, the development of a new regulatory framework for the functioning of the vocational education system, the transfer of vocational education institutions to the subordination of local authorities and the formation of state-public management system.

\section{CONCLUSIONS}

Analyzing and comparing the different historical stages of the development of vocational education on the Ukrainian lands, it can be said that the process of its formation and development has come a long and thorny path that fully reflects the circumstances of the socio-political and economic life of the Ukrainian people. The socio-economic inquiry plays a particularly important role in the formation and development of

31 Лікарчук І. Управління системами підготовки кваліфікованих робітників в Україні (1888-1988 роки) : монографія. К. : Вища школа, 1998. 256 с. 
the vocational education system. Thus, it can be noted that in the period of sustainable economic development of the state and the demand for skilled workers, the decentralization of management of educational institutions takes place, curricula and requirements for the level of knowledge and skills of graduates are updated and unified. Instead, during a period of socio-political or economic decline or transformation, the established system of vocational education declines and collapses, with the subsequent updating and transformation of the educational paradigm in line with social and economic demands. Therefore, it is advisable to consider and analyze professional education at the same time both as a social and educational sphere and as an integral part of the development of the country's economy.

\section{SUMMARY}

The article is devoted to the consideration of peculiarities of the development of vocational education in the national educational space. Historical and pedagogical analysis of the genesis of vocational education has been carried out. The main milestones of the development of professional schooling are considered, and their specific features are indicated. The influence of socio-political and economic factors on the development of vocational education has been proved. It was stated that in the period of sustainable economic development of the state and demand for skilled workers, decentralization of management of educational institutions was also taking place, the content of education and requirements to the level of knowledge and skills of graduates were updated. Instead, during a period of socio-political or economic decline or transformation, the established system of vocational education declined and destroyed, with the subsequent updating and transformation of the educational paradigm in line with social and economic demands. Therefore, it is proved that the development of vocational education should be considered and analyzed at the same time as a social and educational sphere, and as an integral part of the development of the economy of the country.

\section{REFERENCES}

1. Лузан П. Г., Васюк О. В. Історія педагогіки та освіти в Україні : навчальний посібник [2-ге вид., доп. і перероб.]. К. : ДАКККіМ, 2010. 296 с. 
2. Профессиональная педагогіка : учебник для студентов, обучающихся по педагогическим специальностям и направлениям / под. ред. С. Я. Батышева, А. М. Новикова. М. : Издательство ЭГВЕС, 2009. $456 \mathrm{c}$.

3. Артемова Л. В. Історія педагогіки України. К. : Либідь, 2006. 419 c.

4. История педагогики и образования. От зарождения воспитания в первобытном обществе до конца XX в. : Учебное пособие для педагогических учебных заведений / Под ред. академика РАО А. И. Пискунова [2-е изд., испр. и дополн.]. М. : ТЦ «Сфера», 2001. $512 \mathrm{c}$.

5. Історія Львова у документах і матеріалах / М.В.Брик, У. Я. Сдлінська. К.: Наукова думка, 1986. 426 с.

6. Лікарчук I. Управління системами підготовки кваліфікованих робітників в Україні (1888-1988 роки) : монографія. К. : Вища школа, 1998. 256 с.

7. Жук І. Л. Підготовка робітничих кадрів на виробництві: ретроспективний аналіз та оцінка сучасних тенденцій // Демографія та соціальна економіка, 2014, № 2 (22). С. 145-154.

8. Ханин Г. И. Экономическая история России в новейшее время. - Т. 1 : Экономика СССР в конце 1930-х годов - 1987 г. Новосибирск : Из-во Новосибирск. гос. тех. ун-т, 2008. 516 с.

9. Батышев С.Я. Очерки истории профессионально-технического образования в СССР. М. Педагогика, 1981. 351 с.

10. Пузанов М., Терещенко Г. Очерки истории профессионально-технического образования в Украинской ССР. К.: Вища школа, 1980. 232 с.

\section{Information about the author:} Pahuta M. V.

Candidate of Pedagogic Sciences, Associate Professor, Doctoral Student of the General Pedagogy and Preschool Education Department, Drohobych Ivan Franko State Pedagogical University 24, Ivan Franko str., Drohobych, 82100, Ukraine 